DOI: 10.12731/2658-6649-2019-11-5-32-36

УДК 616.076

\title{
ПОЛУЧЕНИЕ ЭПИТЕЛИАЛЬНЫХ КЛЕТОК ИЗ БИОПТАТОВ ЖЕЛУДКА ЧЕЛОВЕКА
}

\author{
Болдырева А.В., Беленюк В.Д.
}

Первичные культуры эпителиальных клеток, использованные в нашей работе, получены из свежих образиов биопсийного материала человека. Протестирован ряд методик, включающих в разном соотношении ферментативные растворы. Методом проточной цитоомтрии полученные культуры клеток оценивали по выживаемости, пролиферации, фенотипического состава и апоптоза.

Ключевые слова: эпителиальные клетки желудка; биопсия желудка; первичная культура.

\section{ISOLATION OF EPITHELIAL CELLS FROM HUMAN GASTRIC BIOPSIES}

\author{
Boldyreva A.V., Belenyuk V.D.
}

The primary cultures of epithelial cells used in our work were obtained from fresh samples of human biopsy material. A number of techniques including enzymatic solutions in different ratios were tested. By the method of flow cytometry the obtained cell cultures were evaluated by survival, proliferation, phenotypic composition and apoptosis.

Keywords: gastric epithelial cells; gastric biopsies; primary culture.

\section{Введение}

Патология желудка занимает одно из ведущих мест в структуре заболеваний органов пищеварения. Ранняя диагностика развития патологии желудка определяет чрезвычайно высокую клиническую и социальную значимость.

Существующие методы лечения патологий желудка направлены на замедление прогрессирования заболевания, остановку и восстановление поврежденных участков слизистой оболочки желудка (СОЖ). Но на практике при назначенном лечении отмечаются побочные эффекты от 
лечения, что приводит к затяжному выздоровлению из-за агрессивного действия препаратов на слизистую желудка. Адекватный подход в лечении патологии желудка включает своевременную терапию по устранению заболеваний и своевременную диагностику предраковых изменений СОЖ $[1,2]$.

Для исключения возникновения изменений со стороны эпителиальных клеток желудка при назначаемой терапии, необходимо заранее знать реакцию СОЖ на препарат.

С помощью метода исследования in vitro представляется возможным оценить ответную реакцию эпителиальных клеток желудка на лекарственное вещество.

Тест-системы in vitro можно использовать преимущественно для возможной оценки взаимодействия назначенного лекарственного вещества с клетками СОЖ из биопсионного материала, тем самым исследовать структурные изменения эпителиальных клеток на тестируемый препарат.

Цель данной работы - выделение и накопление биомассы эпителиальных клеток из биопсии желудка и изучение фенотипических и метаболических характеристик полученных клеток.

\section{Материалы и методы исследования}

Работа выполнена на клетках эпителия слизистой оболочки антрального отдела желудка человека. Образцы биопсий были получены при гастроэндоскопическом обследовании.

Основой для разработки метода получения первичной культуры послужила классическая процедура [3]. В работе были протестированы несколько методик включающих в разном соотношении ферментативные растворы, содержащие коллагеназу, проназу, гиалуронидазу, трипсин (в различных комбинациях). Биопсийный материал промывали раствором Хенкса с антибиотиком, после чего обрабатывали в ферментативных растворах. Затем пропускали через нейлоновый фильтр. Осадок ресуспендировали в полной ростовой среде RPMI-1640 и высевали в чашки Петри с коллагеновым покрытием. Концентрацию клеток определяли в камере Горяева, жизнеспособность - по эксклюзии трипанового синего. После этой процедуры клетки были готовы для использования и хранения. Далее проводили исследования полученной первичной культуры эпителиальных клеток с помощью многоцветной проточной цитометрии на приборе FC 500 (Beckman Coulter, США). 


\section{Результаты исследования}

Применяя классическую описанную методику [3] при выделении первичной культуры клеток удалось выделить малое количество клеток, процент жизнеспособных клеток составлял 30-40\%. Тестируя различные методики выделения клеток, отмечалось, что процент жизнеспособности клеток менялся в зависимости от времени влияния и комбинации ферментативных растворов.

Из полученного при биопсии способом поэтапного применения ферментативных растворов мы получали 10-12 млн. изолированных эпителиоцитов, жизнеспособность которых составляла 85-95\%.

Проводили исследования полученной первичной культуры эпителиальных клеток с помощью многоцветной проточной цитометрии, оценивая выживаемость, пролиферацию, фенотипический состав и апоптоз, где можно оценить выраженность сочетанного воспалительного процесса по маркеру готовности к апоптозу, а уровень пролиферативной активности эпителиальных клеток, может указать на неопластический процесс. В дальнейшем полученная культура клеток может быть подвергнута экспансии путем пассирования.

\section{Обсуждение}

Существующие методики выделения и культивирования эпителиальных клеток желудка не всегда легко воспроизводимы, и часто отягощаются высоким процентом клеток входящих в апоптоз, что в свою очередь критично сказывается на качестве исследований.

\section{Заключение}

Проведенное исследование показало, что полученные эпителиальные клетки из биопсии желудка могут дать адекватную оценку для определения тяжести патологического процесса в слизистой оболочке. В перспективе, получаемая первичная культура эпителиальных клеток из биологического материала биопсии желудка позволит эффективно корректировать назначенную терапию каждого конкретного пациента, и таким образом, исключать изменения, которые могут привести к развитию неопластического процесса.

\section{Список литературь}

1. Габибов Р.С., Дадамов Р.А., Ахмедов Т.С. Проблемы распространения, патогенеза, диагностики и лечения хронического гастрита и язвенной бо- 
лезни, ассоциированных с инфекцией Helicobacter pylori // Доказательная гастроэнтерология. 2017. №4. С. 20-24.

2. Бакулин И.Г., Пирогов С.С., Бакулина Н.В., Стадник Е.А., Голубев Н.Н. профилактика и ранняя диагностика рака желудка // Доказательная гастроэнтерология. 2018. №2. С. 44-58.

3. Фрешин Р.Я. Культура клеток. Практическое руководство. Москва: БИНОМ. Лаборатория знаний. 2010. 692 с.

\section{References}

1. Bakulin I.G.,Pirogov S.S., Bakulina N.V., Stadnik E.A.,Golubev N.N. Prophylaxis and early diagnosis of stomach cancer. Evidence-based gastroenterology, 2018, №2, pp. 44-58.

2. Gabibov R.S.,Dadamov R.A.,Akhmedov T.S. The problems pertaining to the prevalence, pathogenesis, diagnostics, and treatment of chronic gastritis and ulcer disease associated with Helicobacter pylori infection. Evidence-based gastroenterology, 2017, №4, pp. 20-24.

3. Freshin R.Ya. Kul'tyra kletok. Prakticheskoe rukovodstvo [Cell culture. Practical guide]. Moscow: BINOM. Laboratoriya znanij, 2010. 692 p.

\section{ДАННЫЕ ОБ АВТОРАХ}

Болдырева Анна Валериевна, младший научный сотрудник, кандидат биологических наук Федеральное государственное бюджетное научное учреждение «Федеральный исследовательский иентр «Красноярский научный иентр Сибирского отделения Российской академии наук» ул. Академгородок, 50, г. Красноярск, Красноярский край, 660036, Российская Федераџия lampa15@bk.ru

Беленюк Василий Дмитриевич, младший научный сотрудник, лаборатория клеточно-молекулярной физиологии и патологии ФГБНУ Федеральный исследовательский иентр «Красноярский научный иентр Сибирского отделения Российской академии наук», обособленное подразделение «НИИ медицинских проблем Севера» ул. П. Железняка, 32, г. Красноярск, Красноярский край, 660022, Российская Федераиия dyh.88@mail.ru 


\section{DATA ABOUT THE AUTHORS}

Boldyreva Anna Valerievna, Research Assistant, Candidate of Biological Science

Federal Research Center "Krasnoyarsk scientific center» 50, Akademgorodok, Krasnoyarsk, 660036, Russian Federation lampa15@bk.ru

Belenyuk Vasily Dmitrievich, Research Assistant, Laboratory of the Cellular Molecular Physiology and Pathology

Federal Research Center "Krasnoyarsk Science Center》 of the Siberian Branch of the Russian Academy of Sciences, Scientific Research Institute of medical problems of the North

3g, Partizana Geleznyaka, Krasnoyarsk, 660022, Russian Federation dyh.88@mail.ru 